\title{
HAMBATAN PENDAFTARAN INDIKASI GEOGRAFIS TAHU SUMEDANG SEBAGAI ASET POTENSIAL DAERAH
}

\section{REGISTRATION OBSTACLES OF GEOGRAPHIC INDICATIONS TOFU SUMEDANG AS A POTENTIAL REGIONAL ASSET}

\author{
Yudha Agung Nugraha \\ Universitas Pembangunan Nasional Veteran Jakarta \\ Email : $\underline{\text { Yudhaagung08@gmail.com }}$ \\ Imam Haryanto \\ Universitas Pembangunan Nasional Veteran Jakarta ( Pondok Labu) \\ Email : imam.upns1@gmail.com
}

\begin{abstract}
Abstrak
Tujuan penulisan ini mengkaji tentang hambatan pendaftaran indikasi geografis tahu sumedang sebagai aset potensial daerah. Metode penelitian yang digunakan dalam penelitian yaitu penelitian yuridis normatif yang berarti dilakukan dengan cara meneliti bahan pustaka atau bahan sekunder, kemudian menganalisis persoalan-persoalan yang menyangkut tentang Indikasi Geografis dan manfaatnya terhadap daerah asalnya. Hasil analisis memunculkan 2 tema yang dibahas di sini hambatan pendaftaran indikasi geografis tahu sumedang, serta dampak terhadap pencantuman produk sebagai indikasi geografis. Kajian tentang kedua tema tersebut sangat berguna untuk memahami pentingnya pendaftaran indikasi geografis dan juga manfaat yang dihasilkan dengan perlindungan Indikasi Geografis .
\end{abstract}

\section{Kata Kunci: Indikasi Geografis, Sumedang, Manfaat Indikasi Geografis}

\section{Abstract}

The purpose of this paper is to examine the barriers to registering geographic indications of Sumedang as potential regional assets. The research method used in the research is normative juridical research which means that it is carried out by examining library materials or secondary materials, then analyzing issues concerning Geographical Indications and their benefits to the area of origin. The results of the analysis raise 2 themes discussed here, barriers to registering geographical indications of Sumedang tofu, as well as the impact on product listing as geographic indications. A study of these two themes is very useful in understanding the importance of registering geographic indications as well as the benefits generated by protecting Geographical Indications.

Keywords : Geographical Indications, Sumedang, Benefits of Geographical Indications

\section{A. Pendahuluan}

Indonesia merupakan wilayah yang terdiri

dari daratan yang berjumlah 1.922 .570 $\mathrm{km}^{2}$, perairan $3.257 .483 \mathrm{~km}^{2}$, Jika dilihat secara keseluruhan maka total wilayah indonesia sekitar $5.180 .053 \mathrm{~km} 2$, hal ini 
sesuai dengan data serta informasi yang di sampaikan Oleh Badan Informasi Geospasial, Indonesia merupakan negara yang dikenal dengan beragamnya ideologi dan sangat menghargai perbedaan tersebut, sehingga dengan keberagaman perbedaan Indonesia dijuluki sebagai negara multikultural yang didorong oleh faktor banyaknya jumlah penduduk di Indonesia. Beragamnya etnis, budaya, dan kebiasaan berdampak pada ragamnya pangan yang dihasilkan. ${ }^{1}$ Berdasarkan Pasal 1 angka 1 Undang- Undang Nomor 18 Tahun 2012 tentang Pangan bahwa pangan merupakan kebutuhan dasar manusia yang paling utama dan pemenuhannya merupakan bagian dari hak asasi manusia yang dijamin di dalam Undang-Undang Dasar Negara Republik Indonesia Tahun 1945 sebagai komponen dasar untuk mewujudkan sumber daya manusia yang berkualitas. Beberapa contoh produk pangan yang berasal dari Indonesia adalah Kopi Gayo, Ubi Cilembu, Tahu Sumedang dan masih banyak lagi.

Banyaknya pangan yang dihasilkan oleh Indonesia tidak selalu berdampak besar kepada daerah penghasil. Pemerintah memberikan aturan agar pangan yang berasal dari suatu daerah memberikan

\footnotetext{
${ }^{1}$ Undang -Undang Republik Indonesia Nomor 18 Tahun 2012 Tentang Pangan.
}

keuntungan ekonomi bagi wilayah penghasil yakni Indikasi Geografis. ${ }^{2}$ Menurut Undang-Undang Nomor 20 Tahun 2016 Tentang Merek dan Indikasi Geografis Pasal 1 Angka 6 menegaskan bahwa Indikasi Geografis adalah suatu tanda yang menunjukkan daerah asal suatu barang dan/atau produk yang karena faktor lingkungan geografis termasuk faktor alarn, faktor manusia atau kornbinasi dari kedua faktor tersebut memberikan reputasi. Indonesia memiliki suatu pengakuan terhadap suatu Hak kebendaan yang sah serta dijadikan pedoman hukum baik atas benda tidak berwujud yang dapat berupa kekayaan atau kreasi Intelektual, atau dalam hal lain dapat berupa hak cipta, paten, merek dagang, desain Industri, dan Indikasi Geografis. ${ }^{3}$ Indikasi Geografis dapat memberikan dampak yang signifikan bagi daerah asal suatu pangan, seperti hal nya daerah aceh dengan Kopi Gayo yang mana kopi ini sudah terkenal hingga mancanegara yang memberikan dampak yang positif baik untuk daerah asalnya yaitu aceh dan juga petani. Contoh lain yaitu Tahu Sumedang yang sudah terkenal hampir diseluruh wilayah Indonesia. Tahu

\footnotetext{
2 Undang - Undang Republik Indonesia Nomor 20 Tahun 2016 Tentang Merek Dan Indikasi Geografis.

3 Munir Fuady, Pengantar Hukum Bisnis (Bandung : Citra Aditya Bakti, 2012), hlm. 203.
} 
Sumedang memiliki tekstur, dan citra rasa yang khas yang dihasilkan oleh wilayah asalnya yaitu Sumedang dan sudah terdaftar sebagai Indikasi Geografis.

Pokok penelitian ini berasal dari salah satu daerah di Jawa Barat yang berbatasan langsung dengan ibu kota provinsi Bandung, yaitu Sumedang. Kabupaten Sumedang memiliki jumlah penduduk yang mencapai 1 juta jiwa dengan luas wilayahnya 153.124 ha memiliki beragam potensi yang sangat akan bermanfaat seperti hal-nya sumber daya alam, serta hal lainnya seperti makanan khas, kerajinan tradisional, peternakan, kehutanan, dan pertanian. Penelitian ini dikhususkan terhadap produk indikasi geografis yaitu Tahu Sumedang yang mana didalam kajian ini digunakan untuk melihat dampak yang dihasilkan oleh pendaftaraan tahu sumedang itu sendiri sebagai Indikasi Geografis, serta bentuk perlindungan hukumnya bagi kota sumedang itu sendiri yang merupakan daerah asal daripada tahu itu sendiri. ${ }^{4}$

\footnotetext{
${ }^{4}$ Pemerintah Provinsi Jawa Barat. "Kabupaten Sumedang." Pemerintah Provinsi Jawa Barat, 2017, https://iabarprov.go.id/index.php/pages/id/105 1, diakses tanggal 10 November 2019 pukul 07.40 WIB.
}

Perlindungan indikasi geografis dapat membuat masyarakat sejahtera dan daerahnya akan dikenal melalui product yang dihasilkan, serta berdampak terhadap perkonomian masyarakat, baik pengolah tahu maupun pedagang. Meningkatnya pariwisata merupakan salah satu dampak positif dari perlindungan indikasi geografis.

Peran pemerintah terhadap pemberian informasi serta pemahaman masyarakat mengenai indikasi geografis belum secara menyeluruh, sehingga terbatas pengetahuan masyarakat hanya sebatas paten dan merek. Dalam hal lain juga masyarakat perlu memahami tentang Indikasi Geografis. ${ }^{5}$ Pemerintah pusat atau daerah harus berkomitmen mengembangkan faktor alam yang dimiliki oleh suatu daerah, serta peran dari masyarakat itu sendiri yang mana masyarakat disini sebagai faktor pendukung terwujudunya sumber daya manusia yang berkualitas. Perlinungan produk sebagai indikasi geografis mengakibatkan adanya perlindungan hukum oleh Pemerintah. Menurut CST Kansil, "perlindungan hukum adalah segala upaya hukum harus diberikan oleh aparat penegak hukum demi memberikan

${ }^{5}$ Migni Myriasandra, Tinjauan Hukum Atas Peraturan Pemerintah Nomor 51 Tahun 2007 (Jakarta: Universitas Indonesia, 2008), hlm. 5. 
rasa aman, baik secara pikiran maupun fisik dari gangguan dan berbagai ancaman dari pihak manapun". 6 Dalam hal ini berarti Perlindungan Indikasi Geografis bertujuan untuk melindungi kekhasan atau keaslian dari pemalsuan atau pemanfaatan yang tidak seharusnya sekaligus memberi kesempatan dan perlindungan kepada masyarakat wilayah penghasil produk khas untuk mendapatkan manfaat yang maksimal dari produk khas tersebut.

Perlunya pendaftaran produk sebagai indikasi geografis itu perlu diberikan perhatian khusus, selain sebagai daya tarik sektor pariwisata, juga sebagai peningkatan perekonomian daerah. Banyak hal yang dirasakan apabila suatu produk atau barang didaftarkan sebagai indikasi geografis, oleh sebab itu perlunya peran serta pemerintah sehingga konsumen dapat merasakan dampak yaitu mendapatkan jaminan kualitas produk. Pendaftaran yang dimaksud adalah dilakukan oleh masyarakat maupun lembaga perwakilan dengan dokumen yang dilengkapi. ${ }^{7}$

Permasalahan yang penulis angkat adalah tentang bagaimana hambatan

${ }^{6}$ C.S.T Kansil, Pengantar IImu Hukum Dan Tata Hukum Indonesia, (Jakarta: Balai Pustaka, 1989), hlm. 40.

7 Undang- Undang No. 15 Tahun 2001 Tentang Merk. pendaftaran tahu Sumedang sebagai indikasi geografis. Penulis juga mengkaji dampak perlindungan Indikasi Geografis. Berdasarkan paparan sebelumnya, maka penulis memutuskan untuk memberikan Judul Penelitian ini yaitu " Hambatan Pendaftaran Indikasi Geografis Tahu Sumedang Sebagai Aset Potensial Daerah" .

\section{B. Metode Penelitian}

Jenis penelitian ini yuridis normatif dengan menggunakan sumber kepustakaan sebagai bahan dasar atau data sekunder melalui penelusuran literatur untuk menganalisis permasalahan yang dibahas dalam penelitian ini. $^{8}$ Sesuai dengan Penjelasan oleh Soerjono Soekanto menyatakan bahwa penelitian ini memberikan pandangan terhadap definisi pendekatan yurisdis normatif sebagai sebuah penelitian hukum yang mengandalkan terhadap bahan kepustakaan atau dalam kata lain data sekunder, lalu kemudian hal ini dijadikan sebagai bahan dasar dengan melakukan penganalisisan baik terhadap Aturan maupun literature terkait untuk mengkaji penelitian tersebut. $^{9}$

\footnotetext{
${ }^{8}$ Ronny Hanitijo Soemitro, Metode Penelitian Hukum, (Jakarta: Ghalia Indonesia, 1985), hlm. 93.

9 Soerjono Soekanto dan Sri Mamudji, Penelitian Hukum Normatif Suatu Tinjauan
} 
Pendekatan masalah didalam Dokumen Deskripsi mencakup penelitian menggunakan pendekatan peraturan perundang-undangan (statute approach), pendekatan kasus (case approach), dan pendekatan konseptual (conceptual approach). Pengumpulan data menggunakan kajian kepustakaan.

\section{Pembahasan}

\section{Pendaftaran Indikasi Geografis} dan Hambatan Pendaftaran

\section{Tahu Sumedang}

Beberapa Perubahan penting dalam perlindungan Indikasi Geografis diantaranya penggunaan istilah Buku Persyaratan sebagai dokumen yang harus dibuat untuk mendaftarkan barang dan/atau produk sebagaimana terdapat dalam Peraturan Pemerintah Tentang Indikasi Geografis 2007 diganti dengan Dokumen Diskripsi yang diatur dalam Undang-Undang No. 20 tahun 2016 tentang Merek dan Indikasi Geografis. Alasan untuk mengubah istilah tersebut adalah untuk meringankan syarat permohonan pendaftaran. Sejak pemberlakukan Peraturan Pemerintah komunitas produsen terlalu dibebani dalam menyusun Buku Persyaratan Indikasi Geografis.

Singkat, (Jakarta : Rajawali Pers, 2001), hlm.13-14. 
Tahu sumedang adalah pangan khas sumedang yang digunakan dalam berbagai acara religi dan budaya masyarakat Jawa Barat. Sumedang mendapat julukan sebagai Kota Tahu. Produk tersebut sudah banyak dijual oleh masyarakat guna memenuhi kebutuhan ekonomi mereka, karena tahu itu juga sebagai aset potensial daerah. Sesuai juga dengan Berita Resmi

\section{Indikasi Geografis Seri - A No.}

07/Ig/Ii/A/2019 bahwa tahu sumedang ini diusulkan atau didaftarkan oleh Perkumpulan Pengrajin Pengusaha Pedagang Tahu Sumedang.

Pihakidalam pendaftaran Indikasi Geografis Tahu Sumedang atau dalam kata lain pemohon pendaftaran Indikasi Geografis ini terdiri dari Perkumpulan Pengrajin Pengusaha Pedagang Tahu Sumedang, tentunya hal ini memberikan beberapa pertanyaan, terkait yang pertama apakah pihak ini saja yang diuntungkan untuk mendapatkan Hak Ekslusif Indikasi Geografis Tahu Sumedang. Alangkah lebih baiknya bila pendaftaran ini Melalui Badan Hukum Publik yang dalam hal ini melalui Pemerintah daerah Sumedang, agar nantinya dampaknya bukan hanya dirasakan bukan hanya oleh pengrajin, karena Tahu Sumedang ini sendiri merupakan suatu ciri khas Daerah Sumedang. Bila pendaftaran ini dilakukan oleh Pemerintah Sumedang maka proses pendaftarannya pun tidak akan terkendala seperti sekarang. Penulis menangkap beberapa hal kenapa Tahu Sumedang ini belum dilindungi, sebab terkait mengenai Pemangku Kepentingannya dirasa tidak menggambarkan atau memberikan dampak pada daerah penghasilnya itu sendiri akan tetapi lebih kepada pihak yang mendaftarkannya saja. Akan berbeda ketika hal ini didaftarkan oleh Pemerintah Daerah Sumedang, tentunya prosesnya tidak akan terkendala karena dalam hal ini sudah seharusnya indikasi geografis ini sendiri memberikan dampak besar terutama kepada daerah asal Alasan kenapa penulis menyarankan lembaga tersebut karena tentunya adanya uraian baik substantif dan administratif Indikasi Geografis, sehingga berarti adanya syarat untuk menulis buku riwayat yang menguraikan Kedua Hal Tersebut.

b) Produk Atau Objek yang akan dilindungi

Tahu Sumedang telah digunakan oleh masyarakat daerah sumedang sebagai mata pencaharian baik di daerah Sumedang itu sendiri, maupun masyarakat sumedang yang dalam hal lain berada di berbagai daerah mereka memperkenalkan produk tahu sumedang ini dengan cara menjualnya.sehingga dalam hal ini sudah seharusnya tahu Sumedang dilindungi Indikasi Geografis. Pendaftaran Indikasi 
Geografis oleh Jawa Barat itu sendiri sudah berhasil didalam beragam produk Indikasi Geografis seperti halnya Tembakau Mole, Beras Pandanwangi, Sawo Sukatali, Ubi Cilembu, Teh Java Preanger. Gerabah Plered juga masih didalam proses penerbitan sertifikat, maka dalam hal ini status Tahu Sumedang pun sama seperti Gerabah Plered yang mana Pendaftaran sudah dilakukan namun masih perlu peninjauan oleh tim ahli indikasi Geografis Indoneisa baik dari segi persyatan, kelengkapan, maupun keunikan daripada produknya,"Tahun ini akan masuk Tahu Sumedang. Itu benar-benar dilindungi. Itu usulan pemerintah daerah untuk meningkatkan usahanya dan sudah terlindungi. Jadi tidak ada lagi daerah lain yang bisa mengaku. Jadi menguatkan dan melindungi kearifan lokal". ${ }^{12}$

c) Karakteristik, Kualitas, dan Reputasi Produk

\section{(1). Karakteristik Produk}

Perbedaan tahu sumedang dengan tahu biasa seperti tahu putih atau tahu kuning, adalah berbentuk kotak, berwarna kecokelatan, dan bagian

12 Muhammad Fikry Mauludy, "Tahu Sumedang Dan Ubi Cilembu Akan Segera Dilindungi Kemenkumham," PikiranRakyat.com, 2019, https://www.pikiranrakyat.com/bandung-raya/pr-01308665/tahusumedang-dan-ubi-cilembu-akan-segeradilindungi-kemenkumham. luarnya renyah. Lebih nikmat disantap saat masih panas bersama cabai rawit hijau. Salah satu ciri khas dari tahu ini adalah kemasannya. Sejak zaman dahulu hingga sekarang, tahu dikemas dalam wadah dari anyaman bambu dan dilapisi daun pisang, atau disebut bongsang. Pengemasan dengan cara tersebut dapat membuat tahu lebih awet.

(2). Reputasi Produk

Jika melihat Keberagaman yang dimiliki Indonesia, tentu saja dampak ini dirasakan dalam Sektor Pariwisata, sehingga prospek wisata yang berbasis alam ini memiliki keberagaman jenis salah satu bidangnya yaitu wisata kuliner. Wisata tersebut memiliki keunikan serta ciri khas masingmasing dan memiliki perbedaan bagi dari segi rasa, maupun konsep yang ditawarkan. Contohnya jika berkunjung ke Sumedang, wisatawan pasti ingin mencoba kelezatan tahu yang merupakan ciri khas kabupaten Sumedang ini. Tahu Sumedang memang berbeda dengan produkproduk tahu lainnya. Apalagi jika kita merasakan kerenyahan dan kelezatan tahu Sumedang.

d) Fungsi dan Pemasaran Produk Fungsi tahu sumedang tidak hanya sekedar sebagai pangan khas Sumedang 
melainkan juga merupakan bagian dari sejarah kotanya. Hal ini sangat penting karena berkaitan dengan asal muasal produk itu sendiri yang mana produk ini berasal dari sumedang dan lekat dengan sejarah dan budaya sumedang.

\section{e) Keterunutan}

Keterunutan merupakan penomoran khusus produk sebelum di lepas ke pasar.Penomoran akan memudahkan penelusuran produk agar identitas dan sumber atau asal bahan baku tiap produk yang dilindungi oleh indikasi geografis mudah ditemukan. Keterunutan sangat diperlukan untuk mengindentifikasi apakah satu produk ber- indikasi geografis merupakan produk asli yang dibuat oleh para anggota kelompok. Keterunutan indikasi Geografis bersifat tertutup dan hanya diketahui oleh para pemegang hak. Namun, Penomoran dapat dibuat sesuai dengan kesepakatan dalam asosiasi pemegang Indikasi Geografis. Contohnya sebagai Berikut :

(1). Nomor tingkat Pertama, Berdasarkan kabupaten misalnya : Kabupaten sumba barat, sumba barat daya, sumba tengah, dan sumba timur dinomori dengan nomor urut yang diletakkan paling depan

(2). Nomor tingkat kedua, berdasarkan lokasi penghasil di dalam setiap kabupaten, misalnya : Desa lokasi sentra tenun, desa adat, kampung adat yangbelum atau tidak tercatat secara formal sebagai desa adat, tetapi menjadi produsen tenun ikat sumba berdasarkan hak-hak tradisional. Penomorannya diletakkan setelah penomoran tingkat pertama.

(3). Nomor tingkat Ketiga, berdasarkan kualitas kain: Kualitas Premium, Kualitas semi premium, Kualitas baik, Penomorannya diletakkan setelah penomoran tingkat ketiga, dan seterusnya

f) Penggunaan Nama pada Kemasan Produk

Nama atau lokasi yang menggunakan istilah "Tahu Sumedang" atau penyebutan serupa lainnya, jika telah mendapat perlindungan indikasi geografis hanya boleh digunakan pada produk-produk tahu yang berasal dari wilayah sumedang dengan prosentase terbesar pembuatan dilakukan di daerah sumedang itu sendiri dengan mempergunakan bahan-bahan dan pengolahan yang sedapat mungkin berasal dari Sumedang.

g) Pengawasan Kualitas

Pengawasan dan pembinaan dilakukan untuk menjamin bahwa kualitas, dan keamanan tahu sumedang tetap konsisten dengan standar mutu yang telah disepakati oleh seluruh anggota pemegang hak dan dituangkan dalam Dokumen Deskripsi 
Indikasi Geografis. Pengawasan dapat dilakukan melalui beberapa hal seperti, secara eksternal maupun internal. Pengawasan eksternal dilakukan oleh konsumen, lembaga swadaya masyarakat, media serta Tim Ahli Indikasi Geografis yang berasal dari Kementrian Hukum dan Hak Asasi Manusia. Pengawasan internal dilakukan oleh komunitas pemegang Indikasi Geografis, pemimpin adat dari wilayah ulayat tempat produksi berasal, atau orang yang dikuasakan oleh pemimpin adat tersebut. ${ }^{13}$

\section{Tinjauan Dari Sektor Indikasi \\ Geografis}

Tahu Sumedang sebagai pangan khas Sumedang mendorong para pedagang dan masyarakat pengolah serta Pemerintah Daerah Kota Sumedang untuk mendaftarkan produk tahu sumedang sebagai indikasi geografis di wilayah Jawa Barat. Apabila suatu Produk didaftarkan Indikasi Geografis harus memenuhi keaslian produk.

Sesuai Undang- Undang Nomor 20 Tahun 2016 tentang Merek dan Indikasi Geografis, proses pendaftaran Indikasi Geografis itu harus memperhatikan persyaratan yang diminta. Pasal 53 Undang- Undang Nomor 20 Tahun 2015

${ }^{13}$ Ahmad M. Ramli dan Miranda Risang Ayu Palar, Op.Cit. hlm.65. menegaskan bahwa perlindungan bisa dilakukan apabila sudah dilakukan pendaftaran Kepada Menteri. Pendaftaran ini dapat dilakukan oleh 2 Pihak. Pertama, lembaga yang mewakili kepentingan Indikasi Geografis pada wilayah geografis tertentu. Kedua, Pemerintah daerah atau badan hukum publik, hal yang tidak kalah penting berdasarkan Aturan Pasal 14 dan 19 itu menyatakan bahwa pendaftaran indikasi geografis itu bisa dilakukan sekalipun pemohon berada diluar wilayah negara Indonesia, tetapi wajib diajukan tetap oleh kuasanya yang ada di Indonesia. Permohonan harus mendapat pengakuan dari negara asalnya atau sudah didaftarkan sesuai aturan yang terdapat pada negara asalnya.

Proses pendaftaran pengajuan permohonan indikasi geografis juga diatur melalui Peraturan Pemetintah Republik Indonesia Nomor 51 Tahun 2007, yang mencakup persyaratan yang harus dipenuhi, sesuai penjelasan Pasal 5 yakni, format permohonan ini ditulis dengan Bahasa Indonesia, yang dimohonkan oleh pemohon melalui kuasanya. Ketentuan lainnya yaitu formulir diserahkan dalam 3 (tiga) rangkap dan ditujukan kepada Direktorat Jenderal. Bentuk permohonan sudah diatur oleh Direktorat Jenderal.

Ketentuan lainnya yang dimuat didalam Pasal 6 menjelaskan bahwa 
format ini harus berisikan, tanggal pengajuan, bulan pengajuan, maupun tahun pengajuan, serta tak kalah penting yakni nama pemohon itu harus secara jelas bisa individu maupun lembaga perwakilan disertai dengan alamat. bila pemohon menyerahkan permohonan ini kepada Kuasanya, maka harus ada lampiran terkait surat kuasa khusus yang ditulis oleh Pemohon, disertai dengan bukti pembayaran biaya. Pasal 6 juga menjelaskan harus ada nama produk indikasi geografis yang didaftar yang meliputi uraian terhadap ciri khusus produknya, karaktristik, kualitas, serta hal pembeda antara produk indikasi geografis yang diajukan oleh pemohon dengan Indikasi Geografis yang sudah ada, serta faktor lain yang tentunya harus ada yaitu keterkaitan lingkungan geografis dengan produk yang akan didaftarkan. Pembahasan Faktor ini tidak hanya mencakup lingkungan geografis saja, namun faktor alam dan juga masyarakat atau manusianya itu sendiri karena faktor ini memberikan peran penting didalam penjaminan kualitas dan karakteristik dari produk yand dihasilkan. ${ }^{14}$

\section{Pertimbangan Indikasi Geografis}

14 “Peraturan Pemerintah Republik Indonesia Nomor 51 Tahun 2007 Tentang IndikasiGeografis".
Beragamnya produk hasil indikasi geografis mendorong perlunya perlindungan hukum dan keinginan masyarakat untuk mendapatkan perlindungan hukum terhadap produk yang mereka hasilkan, mengingat sumber daya alam yang sangat melimpah di Indonesia. Kekhasan produk Indikasi Geografis Indonesia disebabkan oleh faktor atau unsur letak geografis Indonesia yang sangat strategis. Indonesia memiliki pasar penjualan yang luas dengan jumlah penduduk mencapai 200 juta orang, hal ini mengakibatkan Indonesia sebagai negara yang sangat berperan dalam perdagangan internasional. Pertimbangan Indikasi Geografis ini sangat penting sebab Indonesia sebagai bagian dan anggota dari WTO dan TRIP's Agreement, sehingga memiliki kewajban untuk ikut serta mengembangkan indikasi geografis.

\section{Manfaat Indikasi Geografis}

Indikasi Geografis memiliki beragam manfaat diantaranya pemangku kepentingan indikasi geografis dapat menetapkan Standar Produksi juga untuk mengidentifikasi produk. Indikasi geografis sebagai langkah untuk mencegah praktek persaingan curang, konsumen terlindungi. kemudian indikasi geografis ini juga sebagai penjamin kualitas Produk sehingga memberikan rasa tenang kepada 
para konsumen, selain itu juga indikasi geografis bermanfaat untuk membina produsen lokal, menjalin kerjasama dengan pemegang hak dalam rangka memperkuat citra nama dan reputasi produk. Indikasi geografus memiliki manfaat terhadap pengembangan agrowisata, serta pelestarian lingukan atau alam dan pengetahuan Tradisional, serta Sumber daya Hayati. ${ }^{15}$

\section{Permasalahan-Permasalahan}

\section{Indikasi Geografis}

Permasalahan Indikasi Geografis di Indonesia banyak disebabkan oleh kurangnya perhatian pemerintah salah satunya kurang tegasnya perlindungan hukum terhadap indikasi geogarfis, sehingga dalam praktiknya banyak produk indikasi geografis yang tidak dilindungi. Banyaknya terjadi persaingan curang didalam bidang Indikasi Geografis, penegakan hak dan belum adanya tertib administrasi. Peran tenaga ahli untuk mengawasi dan mengatur produk Indikasi Geografis. Tidak ada pengelolaan dari produsen sebagai alat pengolaan dari pemilik indikasi geografis, kesadaran hukum dari pemangku kepentingan yakni

15 Direktorat Jenderal Kekayaan Intelektual, "Pengenalan Indikasi Geografis," Direktorat Jenderal Kekayaan Intelektual, 2020, https://dgip.go.id/pengenalan-indikasigeografis. pengelola, pengolah, penemu, maupun pendesain indikasi geografis ini menjadi aspek yang belum diperhatikan. Padahal didalam indikasi geografis kesadaran hukum ini sendiri sangat diperlukan agar produsen dapat merasakan manfaatnya.

\section{Proses Dan Perkembangan Tahu Sumedang Didalam Pendaftaran Indikasi Geografis}

Tahu sumedang sudah diproses pendaftaran indikasi geografis wilayah jawa barat sejak tahun 2019. Sesuai dengan data yang didapatkan penulis pada Direktorat Jenderal Kekayaan Intelektual Kementerian Hukum Dan Hak Asasi Manusia Republik Indonesia ${ }^{16}$ dalam Berita Resmi Indikasi Geografis Seri - A No. 07/Ig/Ii/A/2019, tahu sumedang belum ada sertifikat indikasi geografis. Hal tersebut disebabkan belum lengkap persyaratan.

Setelah produk tahu sumedang itu dikategorikan sebagai indikasi geografis maka pemerintah harus memberikan perlindungan hukum terhadap produk tahu sumedang, sesuai dengan definisi

\footnotetext{
${ }^{16}$ Perkumpulan Pengerajin Pengusaha Pedagang Tahu Sumedang, BERITA RESMI INDIKASI GEOGRAFIS SERI - A, 07/IG/II/A/2019 (Indonesia, issued 2019), https://dgip.go.id/images/humas/Berita_Resmi _Indikasi_Geografis/2019/Februari/BRIG07.pdf.
} 
perlindungan hukum oleh philipus m. hadjon, yakni, terdapat pembagian mengenai perlindungan hukum, pertama, bahwa masyarakat diberikan peran untuk menyampaikan pendapatnya, hal ini guna menghindari sengketa yang terjadi antara pemerintah dengan masyarakat, kedua, perlindungan yang terjadi dan digunakan untuk penyelesaian sengketa dengan kata lain perlindungan ini ada ketika sengketa sudah terjadi. ${ }^{17}$

Adapun yang menjadi keterkaitan terhadap perlindungan hukum indikasi geografis yakni:

a) perlindungan hukum preventif bersifat untuk mencegah, mengantisipasi adanya pelanggaran indikasi geografis maka UU No. 20 tahun 2016 tentang Merek dan Indikasi Geografis jo PP no.51 tahun 2007 tentang Indikasi Geografis memberikan perlindungan hukum baik perdata maupun pidana.

b) perlindungan hukum represif bertujuan untuk menyelesaikan sengketa, jika terjadi penyalahgunaan indikasi geografis, maka pemegang hak berhak mengajukan gugatan ganti rugi kepada pengadilan niaga karena pelanggaran hak atau pemakaian indikasi geografis secara tanpa hak

17 Philipus M Hadjon, Perlindungan Hukum Bagi Rakyat Indonesia, (Surabaya : Bina IImu, 1988), hlm. 5. atau melawan hukum.

Sesuai dengan Pemahaman terkait perlindungan Hak Kekayaan Intelektual yang dikemukan oleh Robert $\mathbf{M}$. Sherwood yang merupakan teori pertama yang dikemukakan yakni Reward Theory, yang mengatakan bahwa apabila penemu pencipta atau pendesain layak diberikan penghargaan dan pengakuan terhadap hasil karya intelektual yang dihasilkannya yang mana hal ini sebagai bentuk reward atau imbalan terhadap upaya penemuan atau penciptaan karya intelektual tersebut. Salah satu bentuk pengakuan oleh pemerintah terhadap penciptanya yaitu melalui perlindungan, yang mana perlindungan disini dimaksudkan untuk mengembangkan potensi indikasi geografis sehingga manfaatnya dapat dinikmati oleh setiap masyarakat.

Recovery Theory yaitu bahwa perolehan kembali terhadap hal yang dikeluarkan penemu, pencipta,pendesain yang telah banyak mengorbankan waktu, pembiayaan serta aktivitas yang menggunakan fisik yang lebih untuk menghasilkan karya intelektualnya itu harus mendapatkan kembali apa yang sudah dia keluarkan. Teori Robert M. Sherwood yang ketiga yang sejalan dengan kedua teori diatas adalah Incentive Theory memiliki makna bahwa pendanaan sangat diperlukan untuk mengupayakan 
terpacunya kegiatan-kegiatan penelitian yang dibutuhkan.

Jika dikaitan dengan penelitian ini maka teori-teori yang sudah dijelaskan tersebut memiliki fungsi yang sejalan, yakni perihal pemberian reward atau penghargaan kepada pengolah dan pedagang tahu sumedang atas produk yang telah dihasilkan serta juga peran pemerintah daerah sumedang itu sendiri didalam mendampingi pendaftaran produk tahu sumedang. Upaya preventif difungsikan sebagai sarana untuk mengantisipasi terjadinya kecurangan dari pihak lain yang tidak bertanggung jawab.

\section{Dampak Yang Dihasilkan Tahu} Sumedang Terhadap Perekonomian

\section{Kota Sumedang}

Dalam hal ini terlebih dahulu kita harus mengetahui prinsip ekonomi Hak Kekayaan Intelektual. Jika melihat kaitan antara prinsip ekonomi dan indikasi geografis terlihat bahwa indikasi geografis memiliki nilai ekonomis dimana hal ini berkaitan juga dengan kualitas dan reputasi, sehingga sangat penting pendaftaran indikasi geografis atas barang atau produk hasil produksi daripada sumber daya alam.

Produk indikasi geografis ini mendapatkan perlindungan hukum. kegiatan yang melibatkan Indikasi
Geografis yang memiliki nilai ekonomi dapat memberikan dampak perekonomian yakni mengangkat reputasi kawasan penghasil Indikasi Geografis. Aktivitas yang menunjukan ciri atau karakter sebagai produk unggul di setiap daerah sangat penting. Banyaknya produk unggulan Indonesia yang tidak dilindungi indikasi geografis mengakibatkan pihak luar negeri bebas menggunakannya.

Pendapatan asli daerah (PAD) apabila dijadikan suatu taraf ukur perekonomian suatu wilayah, maka pemerintah Sumedang harus dapat menggali sumbersumber pendapatan, salah satu yang harus dikembangkan adalah terkait potensi hak kekayaan intelektual. Perlindungan indikasi geografis wilayah Sumedang sebagai penghasil tahu sumedang sangat penting untuk meningkatkan kualitas pangan khas sumedang tersebut.

\section{Cara Agar Indikasi Geografis Menjadi Aset Daerah Yang Potensial Untuk Dikomersilkan}

Salah satu manfaat indikasi geografis adalah sebagai aset potensial, sehingga perlunya komersialisasi. Perlu adanya panduan agar indikasi geografis dapat dikomersilkan yakni, pertama, melakukan penilaian kepada setiap wilayah seperti hal nya daerah yang berkaitan dengan reputasi, sehingga nantinya dapat dikenal 
oleh masyarakat luas serta akan berpotensi mendorong perekonomian wilayah tersebut, kedua, melakukan aktivitas pengkajian terkait keunikan sehingga nantinya produk tersebut akan mendapatkan perlindungan hukum, ketiga, penetapan batas geografis yang dalam hal ini memberikan pengaruh yang cukup signifikan terhadap ciri kualitas tersebut. keempat, perlunya pendaftaran produk tersebut sebagai indikasi geografis, kelima, peran pemerintah daerah dalam membuat aturan terkait indikasi geografis yang dihasilkan oleh daerahnya tersebut, gunanya peraturan itu adalah sebagai penjamin agar penghasil atau pendesain produk indikasi geografis menjadi nyaman. Keenam, perlunya pemberian informasi kepada masyarakat terkait pentingnya indikasi geografis terutama untuk daerah penghasilnya itu sendiri. Ketujuh, pembentukan kelembagaan yang mengawasi indikasi Geografis tersebut sehingga nantinya produk tersebut akan terus berkembang dan dampaknya dirasakan oleh daerah khususnya sektor perekonomian. $^{18}$

Tatty Aryani Ramli et al., Urgensi Pendaftaran Indikasi Geografis Ubi Cilembu Untuk Meningkatkan IPM : Cara Agar Indikasi Geografis Menjadi Aset Daerah Yang Potensial Untuk Dikomersilkan Mimbar Volume 26, No. 1, Januari, 2010, hlm 81-91.

\section{Bentuk Kerjasama Yang Dapat Dilakukan Terhadap Produk Indikasi Geografis}

Salah satu bentuk perdagangan yang sangat berdampak perekonomian adalah kegiatan ekspor, kegiatan ini biasanya dilakukan oleh suatu negara yang disebabkan kelebihan barang hasil produksi yang jumlah cukup besar, sehinggaa kegiatan ekspor inilah yang digunakan untuk menjangkau negaranegara yang membutuhkan barang.

Pengembangan perekonomian di daerah indikasi geografis dilakukan dengan kerjasama perdagangan yaitu kegiatan ekspor, yang sangat menguntungkan terhadap daerahnya. Perlu peran pemerintah didalam pengembangan dan pembuatan perjanjian perdagangan terhadap produk indikasi geografis khususnya produk tahu sumedang.

\section{Indikasi Geografis Sebagai Sistem Perlindungan Kolektif Produk} Daerah Dan Katalisator

\section{Pengembangan Ekonomi Kawasan}

Indonesia menempatkan perlindungan indikasi geografis sejalan dengan perlindungan merek, merek kolektif dan merek sertifikasi. Hal ini didasarkan pada fakta bahwa pada tingkat reputasi tertentu, salah satu fungsi perlindungan Indikasi Geografis adalah sebagai identitas yang 
memberikan daya pembeda bagi produk, seperti hal nya merek. Dari sudut pandang konsumen, baik merek, merek kolektif, merek sertifikasi maupun indikasi geografis memiliki fungsi langsung untuk menjamin bahwa konsumen tidak mendapatkan informasi keliru atau digiring secara keliru mengenai asal- usul produk. Dari sisi produsen, baik merek maupun indikasi geografis berfungsi sebagai pengakuan eksistensi, kepemilikan sekaligus jaminan perlindungan sebagai pihak yang benar-benar memproduksi produk. Hal ini secara langsung memperkuat reputasinya sebagai produsen yang andal.

Terkait dengan ekonomi kreatif dalam lingkup pengembangan ekonomi kawasan, indikasi geografis memberikan banyak dampak khususnya kepada pelaku usaha kreatif. Secara ekonomis, indikasi geografis sangat efisien dalam hal pembiayaan karena haknya merupakan produk unggulan kawasan. Penggunaan indikasi geografis dapat secara signifikan melipat gandakan nilai jual dan memberikan nilai tambah dalam pemasarannya. Dampaknya, produk lokal yang telah menyandang indikasi geografis juga dapat menjadi aset bagi pengembangan agrowisata.

Pengembangan sinergis usaha lokal dalam kerangka perlindungan dan pengembangan nilai indikasi geografis akan secara simultan juga mendorong kegiatan pelestarian alam serta peningkatan reputasi kawasan yang ramah lingkungan karena perlindungan kekayaan intelektual ini bergantung pada stabilitas faktor lingkungan wilayah produksinya. jika kualitas lingkungan menurun, karakter produk indikasi geografis pun akan berubah. Perubahan ini, jika dibiarkan bisa mengakibatkan hilangnya karakter produk yang telah digariskan dalam Dokumen Deskripsi Indikasi Geografis sebagai alasan pemberian perlindungan. Hal ini dapat berakibat pada hilangnya perlindungan hukum Indikasi Geografis. ${ }^{19}$

Menurut Laurence Ber'rard dan Philippe Machenay, ada keterkaitan antara kualitas attau reputasi Produk pertanian dengan unsur geografis dari daerah asal produk tersebut dihasilkan. ${ }^{20}$ Indikasi Geografis menjadi alat yang krusial dalam mempromosikan produk yang memiliki karakter Ekologis-Agrikultur lokal, tradisi lokal atau budaya lokal (Local

\footnotetext{
${ }^{19}$ Ahmad M. Ramli dan Miranda Risang Ayu Polat, Op.Cit, hlm. 78.
}

20 Mas Rahmah, Hak Milik Industri Perlindungan Indikasi Geografis untuk Porduk Pertanian : Skenario untuk Mendukung Ketahanan Pangan'. (Makalah Disampaikan Pada Internasioal Conference APHKI di Lombok), hlm. 85. 
Agricultural- ecological, traditional or cultural characteristic). ${ }^{21}$

Indikasi Geografis berpotensi untuk melindungi kata yang berhubungan dengan tempat tertentu. Indikasi Geografis tidak selalu digunakan dalam arti sempit, yaitu perlindungan untuk produk pertanian. Menurut Mevhube Albayrak dan Melda Ozdemi adalah $:^{22}$

a. Indication of source, Indikasi Geografis ini berfungsi untuk menunjukan wilayah atau daerah asal daripada produk.

b. Diffrerentiation, indikasi geografis berfungsi untuk membedakan produk satu sama lain yang terdapat di pasar yang berasal dari wilayah yang berbeda dan memiliki ciri khusus yang berbeda juga.

c. Indication and Quality Guarantee, indikasi geografis diarahkan guna menunjukan dan menjamin kualitas produk yang berkelanjutan serta guna menunjukan persepsi positif dari konsumen atas produk yang terkait.

d. Traditional Knowledge protection, ciri khusus Indikasi Geografis adanya pengaruh faktor budaya, pengetahuan tradisional serta faktor alam yang

\footnotetext{
${ }^{21}$ Mas Rahmah, Op.Cit, hlm. 103.

${ }^{22}$ Ahmad M. Ramli dan Miranda Risang Ayu Polat, Op.Cit, hlm. 88.
}

terjaga dan tercipta dalam waktu yang relatif lama. Perlindungan terhadap Indikasi Geogratis berarti kita telah mengetahui Pengetahuan Tradisional.

e. Local Promotion, indikasi geografis dapat meningkatkan promosi terhadap wilayah tempat produk itu dihasilnya atau dalam hal ini daerah yang menghasilkannya. Hal inilah yang menyebabkan kata yang berkaitan dengan daerah tertentu dapat pula mendapat perlindungan Indikasi Geografis.

\section{Kajian Perbedaan Terkait}

\section{Pemegang Hak Indikasi Geografis}

Melihat dari berbagai Negara contohnya Amerika Serikat, terkait pengaturan Indikasi Geografis itu dapat dilakukan dengan menggunakan Sistem Merek Sertifikasi. Hal tersebut mengakibatkan sistem perlindungna yang ada di Amerika Serikat terhadap produk Indikasi Geografis menjadi tergolong luas, karena sistem ini dapat memungkinkan individu, klub, institusi swasta, ataupun Institusi Pemerintah menjadi Pemegang Hak. Di Amerika Serikat Khususnya pada Departement Pertanian juga memegang merek sertifikasi atas merek multiproduk. indvidu dapat menjadi pemegang atas hak indikasi geografis asalkan melalui pendaftaran merek sertifikasi, oleh sebab 
itu, pemegang hak di Amerika Serikat dalam bidang indikasi geografis tidak hanya tipikal kolektif ataupun komunal seperti yang umum berlaku di negaranegara lain, terutama di negara komunis yang ada di eropa, tapi juga individual. ${ }^{23}$

Dalam hal penggunaaan merek sertifikasi terhadap produk indikasi geografis dapat menyebabkan individu atau dalam hal lain kelompok yang memegang hak sistem di Amerika Serikat baik yang dipegang atau didaftarkan oleh sekelompok untuk dilindungi sebagai merek kolektif. Kolektivitas yang dimaksud lebih kepada pihak yang berwenang seperti koperasi, asosiasi, kelompok kerja ataupun organisasi. Merek kolektif ini tentunya beda dengan merek sertifikasi, merek kolekrif sangat berpotensi untuk mendapatkan hak ekslusif atas merek-nya tersebut. Hal ini membuat perlindungan indikasi geografis menjadi lebih kuaat daripada jika hanya dilindungi oleh merek sertifikasi, sebab merek sertifikasi tidak memberikan hak ekslusif, tetapi hanya memberi sertifkasi atau penjaminan terkait kandungan produk. ${ }^{24}$

23 Miranda Risang Ayu, Geographical Indications Protection in Indonesia Based On Cultural Rights Approach, (Jakarta: Nagara, 2009), hlm. 91.

${ }^{24}$ Ibid, hlm. 83.
Catatan penting mengenai Sistem Perlindungan di Negara Amerika Serikat yakni, reputasi merupakan suatu kewajiban pada saat suatu indikasi geografis akan diajkukan pendaftaran. Hal ini disebabkan oleh sistem merek, bahwa indikasi geografis atau penanda asal geografis, jika wujudnya adalah nama tempat, maka akan dikategorikan kedalam merek deskriptif, karena hanya bersifat terhadap produk merek yang akan dilindungi, sehingga merek ini daya pembedanya lemah. Terkait merek deskriptif yakni suatu tanda asal geografis yang mana menunjukan nama wilayah aatau tempat yang hanya merupakan keterangan asal tempat, diakui keberadannya diharuskan dan dilindungi kebenarannya sebagai nama dagang (trade name) atau indikasi asal (indication of source) yang tidak mensyarakatkan pendaftaran. $^{25}$

Lembaga publik di Amerika Serikat mempunyai wewenang untuk melakukan perlindungan terhadap indikasi geografis, baik terhadap pengembangan produk yang akan dilindungi tersebut. Amerika Serikat memiliki lembaga publik seperti biro alkohol, tembakau, perpajakan, dan perdagangan yang menetapkan wilayah budidaya, jenis serta kualitas daripada

${ }^{25}$ Undang- Udnang Nomor 20 Tahun 2016 Tentang Indikasi Geografis, Pasal 1 dan Pasal 63. 
anggur serta tembakau amerika, lembaga atau biro ini nantinya mendaftarkan produk tersebut yakni produk indikasi geografis untuk minuman anggur dan lembaga ini mempunyai tugas lain yakni mengelola perdagangan serta perpajakan. Terkait produk unggulan yang berupa kopi bahkan yang ada di direktorat khusus, yaitu direktorat kopi, fungsi direktorat ini yakni untuk dapat membantu didalam mendaftarkan atau produk kopi untuk memakai merek sertifikasi sebagai persona hukum. Pada intinya Amerika Serikat dapat melindungi indikasi geografis sebagai hak komunal maupun hak individual. Kewenangan penjamin produk indikasi geogfis ini tentunya melalui serifikasi oleh lembaga publik.

\section{Kesimpulan}

Pihak didalam pendaftaran Indikasi Geografis Tahu Sumedang adalah Perkumpulan Pengrajin Pengusaha Pedagang Tahu Sumedang. Menurut penulis, hal tersebut menjadi salah satu faktor penghambat proses pendaftaran indikasi geografis karena terkait pemangku kepentingannya yang tidak memberikan dampak pada daerah penghasil produk.

Pendaftaran indikasi geografis tahu Sumedang berdampak pada sektor ekonomi, khususnya dalam lingkup pengembangan ekonomi kawasan.
Penggunaan indikasi geografis dapat secara signifikan melipat gandakan nilai jual dan memberikan nilai tambah dalam pemasarannya. Dampaknya, produk lokal yang telah menyandang indikasi geografis juga dapat menjadi aset bagi pengembangan agrowisata.

\section{Daftar Pustaka}

\section{Buku}

Ahmad M. Ramli dan Miranda Risang Ayu Polar, Hukum Kekayaan Intelektual Indikasi Geografis Dan Kekayaan Tradisi Dalam Teori Dan Praktik, Bandung : Refika Aditama, 2019.

\section{C.S.T Kansil. Pengantar Ilmu Hukum Dan} Tata Hukum Indonesia, Jakarta : Balai Pustaka, 1989.

Migni Myriasandra, Tinjauan Hukum Atas Peraturan Pemerintah Nomor 51 Tahun 2007, Jakarta : Universitas Indonesia, 2008.

Miranda Risang Ayu, Geographical Indications Protection in Indonesia Based On Cultural Rights Approach, Jakarta : Nagara, 2009.

Munir Fuady, Pengantar Hukum Bisnis, Bandung : Citra Aditya Bakti, 2012.

Peter Mahmud Marzuki, Penelitian Hukum, Jakarta : Kencana Prenada Media Group, 2006.

Philipus M Hadjon, Perlindungan Hukum Bagi Rakyat Indonesia, Surabaya: Bina Ilmu, 1988.

Ronny Hanitijo Soemitro, Metode Penelitian Hukum, Jakarta : Ghalia 
Indonesia, 1985.

Soerjono Soekanto dan Sri Mamudji, Penelitian Hukum Normatif Suatu Tinjauan Singkat, Jakarta : Rajawali Pers, 2001.

Soerjono Soekamto, Pengantar Penelitian Hukum, Jakarta : Universitas Indonesia, 2010.

\section{Peraturan Perundang-Undangan :}

Undang- Undang No. 15 Tahun 2001 Tentang Merk.

"Undang-Undang Republik Indonesia Nomor 18 Tahun 2012 Tentang Pangan.

Undang-Undang Republik Indonesia No. 20 Tahun 2016 Tentang Merek dan Indikasi Geografis

Peraturan Pemerintah Republik Indonesia Nomor 51 Tahun 2007 Tentang Indikasi Geografis.

\section{Karya Ilmiah :}

Mas Rahmah, Hak Milik Industri

Perlindungan Indikasi Geografis untuk Porduk Pertanian : Skenario untuk Mendukung Ketahanan Pangan'. (Makalah Disampaikan Pada Internasioal Conference APHKI di Lombok).

Tatty Aryani Ramli et al., Urgensi Pendaftaran Indikasi Geografis Ubi Cilembu Untuk Meningkatkan IPM : Cara Agar Indikasi Geografis Menjadi Aset Daerah Yang Potensial Untuk Dikomersilkan Mimbar Volume 26, No. 1, Januari, 2010

\section{Website :}

Direktorat Jenderal Kekayaan Intelektual. "Pengenalan Indikasi Geografis." Direktorat Jenderal Kekayaan Intelektual, 2020. https://dgip.go.id/pengenalanindikasi-geografis.

Muhammad Fikry Mauludy. "Tahu Sumedang Dan Ubi Cilembu Akan Segera Dilindungi Kemenkumham." PikiranRakyat.com, 2019. https://www.pikiranrakyat.com/bandung-raya/pr01308665/tahu-sumedang-dan-ubicilembu-akan-segera-dilindungikemenkumham.

Pemerintah Provinsi Jawa Barat. "Kabupaten Sumedang." Pemerintah Provinsi Jawa Barat, 2017. https://jabarprov.go.id/index.php/page s/id/1051.

Perkumpulan Pengerajin Pengusaha Pedagang Tahu Sumedang. BERITA RESMI INDIKASI GEOGRAFIS SERI - A. 07/IG/II/A/2019. Indonesia, issued 2019. https://dgip.go.id/images/humas/Berit a_Resmi_Indikasi_Geografis/2019/Fe bruari/BRIG-07.pdf. 